
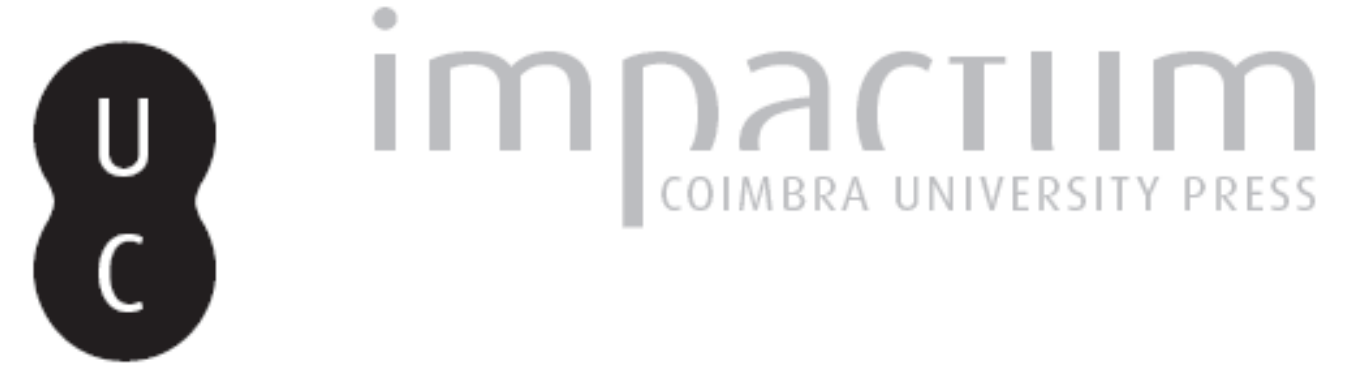

\title{
A case of osteomyelitis in the hip of a Medieval Portuguese male skeleton
}

Autor(es): $\quad$ Ferreira, Maria Teresa; Silva, Ana Maria

Publicado por: CIAS - Centro de Investigação em Antropologia e Saúde

URL persistente:

URI:http://hdl.handle.net/10316.2/41262

DOI:

DOI:http://dx.doi.org/10.14195/2182-7982_19_6

Accessed : $\quad$ 26-Apr-2023 06:21:05

A navegação consulta e descarregamento dos títulos inseridos nas Bibliotecas Digitais UC Digitalis, UC Pombalina e UC Impactum, pressupõem a aceitação plena e sem reservas dos Termos e Condições de Uso destas Bibliotecas Digitais, disponíveis em https://digitalis.uc.pt/pt-pt/termos.

Conforme exposto nos referidos Termos e Condições de Uso, o descarregamento de títulos de acesso restrito requer uma licença válida de autorização devendo o utilizador aceder ao(s) documento(s) a partir de um endereço de IP da instituição detentora da supramencionada licença.

Ao utilizador é apenas permitido o descarregamento para uso pessoal, pelo que o emprego do(s) título(s) descarregado(s) para outro fim, designadamente comercial, carece de autorização do respetivo autor ou editor da obra.

Na medida em que todas as obras da UC Digitalis se encontram protegidas pelo Código do Direito de Autor e Direitos Conexos e demais legislação aplicável, toda a cópia, parcial ou total, deste documento, nos casos em que é legalmente admitida, deverá conter ou fazer-se acompanhar por este aviso.

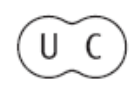


Antropologia Portuguesa

Volume $19 \cdot 2002$

Departamento de Antropologia | Universidade de Coimbra 


\title{
A case of osteomyelitis in the hip of a Medieval Portuguese male skeleton
}

\author{
Maria Teresa Ferreira, Ana Maria Silva \\ Departamento de Antropologia \\ Universidade de Coimbra \\ 3000 - 056 Coimbra, Portugal \\ teresasferreiraejyahoo.com
}

Abstract In the summer of 2001, during an emergency excavation in the "Alta", on old part of Coimbra, 45 skeletons and an ossuary were recovered. One of them, an adult male skeleton, exhumed from a stonelined grave, dated to $1030 \pm 100 \mathrm{BP}$ ( 2 sigma: cal AD $780-1220$, Beta 158253), presented several pathologies, the more striking one affecting the hip. In this articulation, the pathological findings in the femoral head and the acetabulum include extensive bone destruction and reactive new bone formation, involving an irregular surface with pitting and cavities. In the acetabulum a small cloaca is visible. The condition described corresponds to a case of osteomyelitis, probably the consequence of a previous traumatic event affecting the femur's neck.

Key words Male skeleton; osteomyelitis; femoral neck fracture; Medieval necropolis; Coimbra.

Resumo No Verão de 2001, durante uma escavação de emergência na Alta de Coimbra, foram exumados 45 esqueletos e um vasto ossuário. $O$ estudo do esqueleto (número 44), indivíduo adulto do sexo masculino, datado de $1030 \pm 100 \mathrm{BP}$ (2 sigma: cal AD $780-1220$, Beta - 158253), exumado de uma sepultura de pedra, apresenta várias patologias, com relevância para a da anca. Nesta articulação, as lesōes patológicas na cabeça femoral e no acetábulo incluem destruição óssea e formação de osso novo, originando uma superfície irregular com osteófitos. Uma pequena cloaca é visível no acetábulo. A patologia descrita corresponde a um caso de osteomielite, consequência provável de uma lesão traumática no colo femoral.

Palavras-chave Esqueleto masculino; osteomielite; fractura da cabeça femoral; Necrópole Medieval; Coimbra. 


\section{Introduction}

In the year of 2001, the repair of drain pipes in the old high part of Coimbra, "Alta", lead to the discovery, near the Rua Joaquim António de Aguiar, of an old cemetery. This necropolis was probably linked to an already disappeared church, $\mathrm{S}$. Cristovão (nowadays Teatro Sousa Bastos). This church was used between the $12^{\text {th }}$ and $19^{\text {th }}$ centuries (Gambini, 1999).

For seven weeks a team from the Departamento de Antropologia, Universidade de Coimbra and an archaeologist from Câmarn Municipal de Coimbra excavated an area of this necropolis $\left(8 \mathrm{~m}^{2}\right)^{1}$, recovering 45 skeletons plus more than 3000 disarticulated bones fragments. The individuals were exhumed from stone-lined graves or directly from the soil. According to the results of radiocarbon dating of bones from three skeletons, this area of the cemetery was used between the $9^{\text {th }}$ and $13^{\text {th }}$ centuries, and the skeleton here reported dated to $1030 \pm 100 \mathrm{BP}$ ( 2 sigma: cal AD $780-1220$, Beta 158253).

The skeletal sample includes 34 adults, of which 12 were female, 17 male and the sex of the remaining 5 was impossible to establish. In the 11 sub adults, all age groups are represented (Silva and Codinha, 2002).

The more remarkable pathologies were found in the last skeleton (number 44) exhumed from this necropolis, which is the focus of this paper. This individual was inhumed in a rectangular stone-lined sepulture, unique in its typology in the excavated area.

The skeleton was complete but in a poor state of preservation. Sex and age, assessed on the basis of coxal morphology (Buikstra and Ubelaker, 1994), indicated that the skeleton was that of a mature adult male aged more than 50-60 years. Utilising the formulae of Olivier et al. (1978), the femur gave a stature of $167 \pm$ $3.48 \mathrm{~cm}$.

${ }^{1}$ The total area of this Necropolis is unknown. 


\section{Pathological description}

The main pathological features affected the right hip. They are characterised by extensive bone destruction and reactive new bone formation, involving an irregular surface with pitting and cavities.

The right femur shows extensive new bone formation around its head and neck and signs of active infection (Figures 1 and 2).

In the acetabulum a small cloaca opens towards the obturator foramen (Figure 3). Its cavity displays active periostitis with surrounding bone spicule formation (Figure 4).

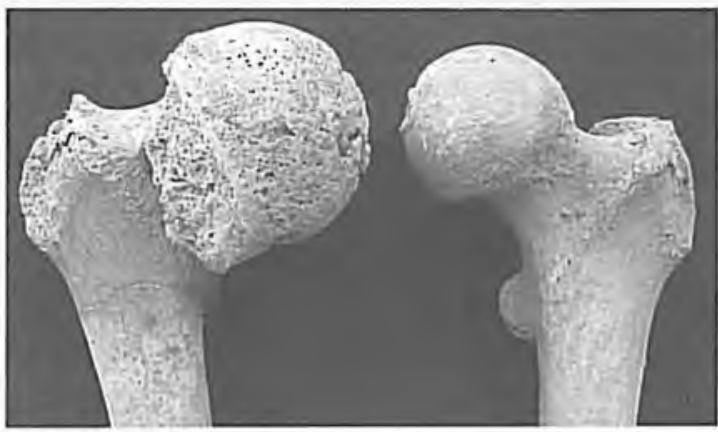

Figure 1. Comparison between the pathological femur (on the left side of the picture) and the opposite unaffected side (anterior view).

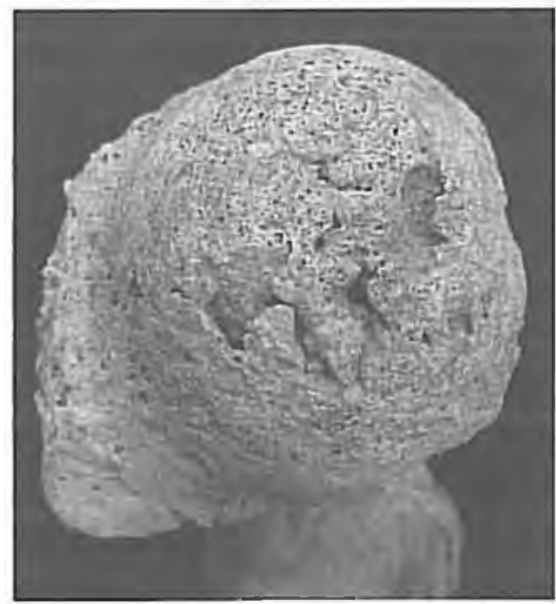

A

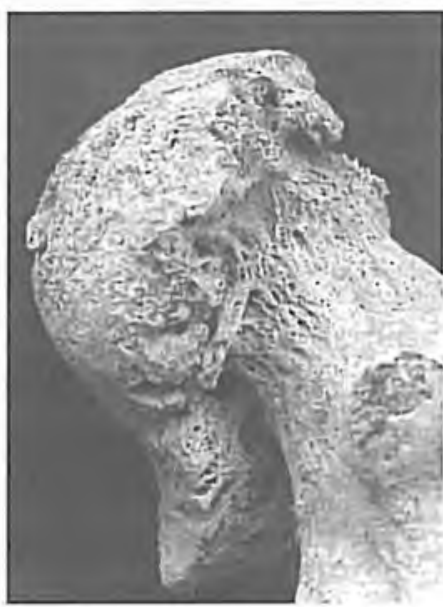

B

Figure 2. Right femur head displaying extensive bone formation around the head and neck, and signs of infection: A. Medial view; B. Posterior view. 


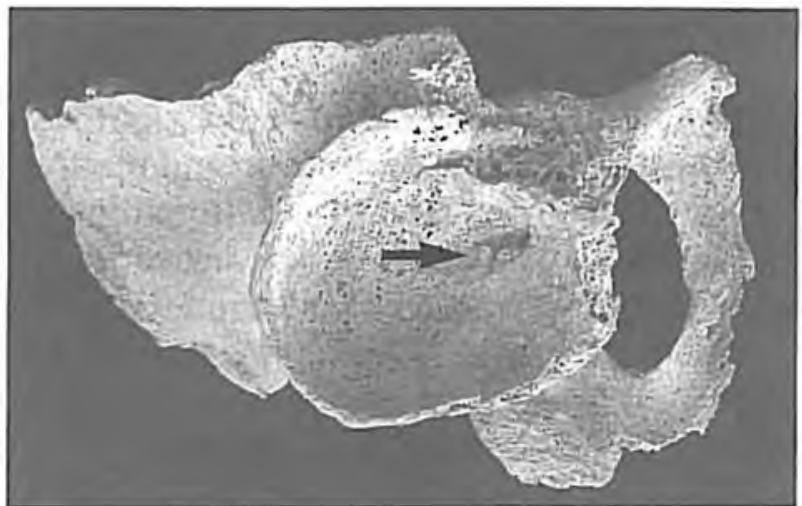

Figure 3. Pathological right coxal bone. The cloaca (arrow) opens towards the obturator foramen.

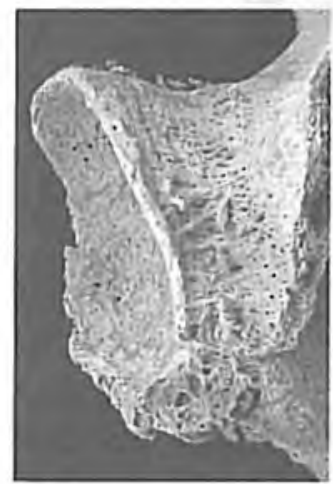

A

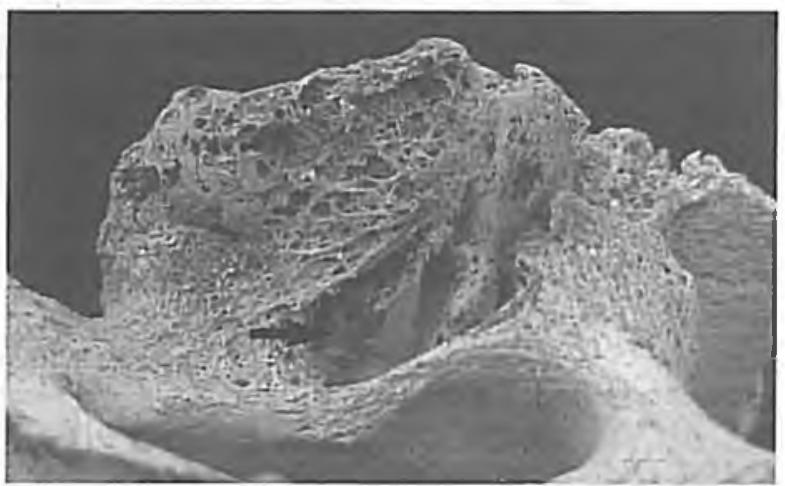

B

Figure 4. Right coxal bone: $A$. Bone spicule formation surrounding the acetabulum (superior view); B. Cloaca (arrow) located near the obturator foramen (medial view).

The appendicular skeleton exhibits generalised osteoarthritic lesions. In the lower thoracic and lumbar vertebrae these alterations are more severe, including the partial collapse of the body of the $12^{\text {th }}$ thoracic vertebra.

\section{Differential diagnosis}

The most likely diagnosis in this case is osteomyelitis. This infection was probably a consequence of previous trauma at the 
femur's neck. Radiographic analysis showed an old fracture line on the femur neck. This kind of fracture is one of the most common in people with osteoporosis in addition to the vertebral collapse. Age-related bone mass loss is a normal phenomenon that affects both sexes above age 60, and features loss of both trabecular and cortical bone with hip and vertebral fractures (Aufderheide and Rodríguez-Martín, 1998; Ortner, 2003).

Legg-Calvé-Perthes disease is a circulatory disorder and is usually unilateral. The superior and anterolateral aspects of the femoral head are the most affected, showing a deformation with a 'mushroom' shape, a characteristic not observed in the present case, and a lack of the foven capitis (Ortner, 2003).

Another disease that can be excluded is slipped capital femoral epiphysis. This is an adolescent condition characterised by an infero-posterior displacement of the femoral capital epiphysis, fusing with the neck in that position (Aufderheide and RodriguezMartín, 1998; Ortner, 2003). Unilateral cases are more common for the left femur. In this case the right femur has deformation of the femoral head but no slippage.

Absence of a new joint for the femoral head allows the exclusion of congenital hip dislocation. In this situation, the femoral head is not in a normal position in the acetabulum, and undergoes complete or partial displacement out of the acetabulum, with the development of a false acetabulum.

\section{Conclusion}

After differential diagnoses were considered, aetiologies such as Legg-Calvé-Perthes disease, slipped capital femoral epiphysis and congenital hip dislocation were rejected.

The results of the palaeopathological study performed on the adult male skeleton number 44 exhumed from the cemetery discovered near the Rua Joaquim António de Aguiar (Coimbra), indicate that he was affected by osteomyelitis in the right hip, probably secondary to a fracture of the femoral neck. 
From this cemetery, two more adult skeletons display similar but less severe degenerative and infectious lesions.

\section{Acknowledgements}

Instituto Ambiente e Vida; Sónia Codinha and Eugénia Cunha (Departamento de Antropologia, Faculdade de Ciências e Tecnologia, Universidade de Coimbra); Câmara Municipal de Coimbra (Gabinete de Arqueologia).

\section{Bibliography}

Aufderheide, A. C.; Rodríguez-Martín, C. 1998. The Cambridge encyclopedia of human paleopathology. Cambridge, Cambridge University Press.

Buikstra, J.; Ubelaker, D. (eds.) 1994. Standards for data collection from Intman skeletal remains. Proceedings of a seminar at the Field Museum of Natural History. Fayetteville, Arkansas Archeological Survey. (Arkansas Archeological Survey Research Series; 44).

Gambini, L. I. 1999. Tentro Sousn Bastos: as primeiras décadas da história. Coimbra, Comissão de Coordenação da Região Centro. (História Regional e Local; 3 ).

Olivier, G.; Aaron, C.; Fully, G.; Tissier, G. 1978. New estimations of stature and cranial capacity in modern man. Joumal of Human Evolution, 7(6): 513-518.

Ortner, D. J. 2003. Identification of pathological conditions in human skeletal remains. $2^{\text {nd }}$ edition. San Diego, Academic Press.

Silva, A. M.; Codinha, S. 2002. Antigo cemitério da Alta de Coimbra. Estudo de uma amostra óssen humana exumada junto à rua Joaquim António de Aguinr (Coimbra). Relatório técnico-científico. Departamento de Antropologia, Universidade de Coimbra. [Unpublished]. 